\title{
Is Long-Term Cell Phone Use Linked to Breast Cancer? A Review of the Evidence
}

\author{
Saddig D. Jastaniah \\ Diagnostic Radiology Department, Faculty of Applied Medical Sciences, King Abdulaziz University, Jeddah, Saudi Arabia \\ Email:sjastaniah@kau.edu.sa
}

How to cite this paper: Jastaniah, S.D. (2016) Is Long-Term Cell Phone Use Linked to Breast Cancer? A Review of the Evidence. Advances in Breast Cancer Research, 5, 136141.

http://dx.doi.org/10.4236/abcr.2016.54016

Received: August 1, 2016

Accepted: September, 3, 2016

Published: September 6, 2016

Copyright (C) 2016 by author and Scientific Research Publishing Inc. This work is licensed under the Creative Commons Attribution International License (CC BY 4.0)

http://creativecommons.org/licenses/by/4.0/

\begin{abstract}
Cancer of the breast is the second leading cause of cancer death among women worldwide. The majority of cancer of the breast cases (95\%) is not hereditary. Can long-term cell phone use be linked to breast cancer? It is unlikely that electromagnetic radiation is involved, but it could possibly be due to the generated heat (cell phones only occasionally transmit when people are not talking on them). Therefore, is there any method or reported statistics that can be used to link the increasing breast cancer incidence with cell phone use and placement? Some young women who placed their mobile devices, including cell phones, in their bra believed that it caused their cancer because it was on the same side and in the same area their phone was adjacent to and came into contact with their skin for prolonged periods. This review highlights what is known about the link between cell phone use, which continues to increase rapidly, and breast cancer explores the association between prolonged exposure to non-ionizing radiation from cell phones and breast cancer. In conclusion, until more data are obtained concerning whether carrying a cell phone is associated with breast cancer, great care should be taken to avoid any potential risks. Strenuous efforts should be made to encourage users of cell phones to follow mobile device manufacturers' recommendations, and if possible, to avoid skin contact until the potential risks, if there are any, are fully understood.
\end{abstract}

\section{Keywords}

Cell Phone, Breast Cancer, Microwaves

\section{Introduction}

The incidence of women cancer of the breast below the age of 40 is low, and it is even lower in the absence of any history from her family related to genetic predisposition. There is thus a need to explore other possible predisposing or possible environmental 
causes that can account for these few remaining breast cancer cases. The American Cancer Society [1] identified a group of female patients aged 21 - 39 years old with invasive multifocal breast cancer. There were thus increased concerns related to exposure to cell phones electromagnetic field to non-ionizing radiation. These women that carry their cell phones directly against their breasts in their brassieres for up to 10 hours per day for several years have developed breast cancer immediately beneath the placement of their phones without any family history of breast cancer. A review of their imaging breast scans revealed the presence of multiple clustering tumor foci directly under the area of phone contact with the breast. Such occurrences raised the issue of a lack of safety information in cases of direct contact with cell phones for long periods of time. In general, it is unlikely that women would consider such placement of their cell phone could lead to breast cancer. Therefore, cell phones, which are frequently used, would be considered harmless, yet recent research has reported that there may be a relationship between tumor growth in the breast and non-ionizing cell phone radiation [2].

\section{The Potential Risk of Cancer of the Breast from Cell Phone Radiation}

The development of invasive cancer of the breast will occur in one out of eight women over a lifetime and one out of 36 will die from it. Although breast cancer rates are decreasing thanks to early diagnosis, there are more than 2.8 million cancer of the breast survivors in the United States (US) [1].

Cell phones are radios for two-way microwaves that should not be kept close to the body. The soft fatty breast tissue readily absorbs such radiation. There are a series of case detected on young women who developed breast cancer despite not having a family predisposition to breast cancer. The breast tumors were present unusually close to the skin where they had placed their cell phones in their bras. Doctors advise women not to keep their cell phones in their bra. In a recent research investigation performed by Volkow et al. [3], women received fluorodeoxyglucose-PET scans, which revealed that levels of glucose metabolism had increased due to radiofrequency exposure waves similar to those produced by cell phones, but the clinical significance of such findings was unclear.

The risk of a woman developing cancer is influenced by many factors, including genetic and environmental factors. However, breast cancer occurs infrequently in younger women (less than 40 years of age) who have no family predisposition or genetic history; yet, some of these women do get the disease, which raises suspicions that environmental triggers may play a role [4].

The collected data from most previous studies on cell phones was acquired in the 2000s, and since then, cell phones have become widespread for many reasons(e.g. because of relatively low prices and marketing), which is beyond the scope of this review. In 2011, it was estimated that the number of subscribers for mobile device services, including those for tablets and cell phones, rose above 300 million in the US, and the number of worldwide subscribers topped 6 billion [5]. Young adults and children are 
now more than ever seen carrying tablets and cell phones and are spending a considerable amount of time with a cell phone in close proximity to their body [6]. Unfortunately, this puts this growing number of users at the highest risk of harm related to electromagnetic radiation (e.g. prepubertal breast buds, the growth of which is potentially believed to be linked to adverse biological consequences of radiation [7]. Some young users have opened themselves up to even greater exposure, as they have been seen carrying more than one device, which might indeed increase their risk even more.

Cardis [8] reported that keeping a mobile phone in one's bra might induce breast cancer. He saw relatively young patients with breast cancer, 39 years old or less, so there would be little chance that some other environmental factor was the cause. He also reported that the women themselves believed that the cancer was due to having kept their cell phone in their bra. In the case of a young woman with breast cancer at age 21, her breast MRI revealed a typical pattern of ductal enhancement, where the "bright spot" accompanied a ductal distribution.

In 2013, a study conducted at the University of California reported that four women aged 21 - 39 years were diagnosed with multifocal breast cancer that originated at different locations in the breast [9]. The medical history of these women revealed that there was no family predisposition to breast cancer. However, these women all regularly kept their cell phones in their bra adjacent to their breast during the day, which was estimated to be about 10 hours every day for several years. Each presented with tumors in the same regions of their breasts, next to where their phones were kept.

A young woman was of the opinion that keeping her mobile phone in her bra led to her cancer. She believed it was because her breast cancer was diagnosed in the same breast and at the exact location where her mobile phone usually came into contact with the skin of her breast. She said that for the past three to four years she usually had her mobile phone in contact with her breast and that her cancer was discovered right where the phone was kept all the time. To explain this event scientifically, a study was conducted by Schuz et al. [2] and they noted immediately that she carried her mobile phone as described, and that it roughly covered the upper outer quadrant of her breast, which is a common location for breast cancer to occur because of the presence of more breast tissue, in accordance with breast anatomy. They then concluded that this was only a coincidence.

In another case, a mother attributed her 21-year-old daughter's breast cancer to her mobile phone, because her daughter kept her cell phone in her bra, and she was healthy and young, with no history of breast cancer in her family or any genetic predisposition to cancer [10].

Observations in experimental studies to assess the effects associated with the use of mobile phones in humans cannot be directly related to conventional mechanisms of thermal injuries. The effects observed are within the range of normal physiology, and are therefore difficult to ascertain with respect to increased health risk. However, it can be concluded that mechanisms other than established thermal mechanisms exist. Because of the present fragmentary scientific database, a precautionary approach is rec- 
ommended when dealing with the effects of radiation from radio and microwave frequencies on the individual and the general population [4].

Breast cancer occurs sporadically in women in the postmenopausal period without any family history or predisposition. Breast cancer is uncommon in younger women (20 - 30 years old). The incidence is $<5 \%$ of all breast cancer cases, the latter of which is normally associated with a genetic predisposition. Hardell et al. [10] [11] detected four cases of multifocal sporadic breast cancer in younger women, indicating a potential correlation between direct skin contact of mobile devices for long periods with breast cancer. To date, there is no clear clinical or scientific evidence to suggest a significant correlation between the risk of breast cancer and exposure to electromagnetic radiation resulting from cellular device emissions. Few research and scientific articles have described that such a relationship exists, whereas other studies have not confirmed such a relationship, although the International Agency for Research on Cancer did classify electromagnetic radiation as radiofrequency waves emitted by mobile devices as a possible predisposing cause of cancer [12].

Electromagnetic radiation emitted by cell phones results in both a thermal and nonthermal biological effect. It was reported that radiofrequency waves, which are part of electromagnetic radiation, have insufficient ionization energy to affect molecules and are unable of causing direct damage to DNA [13]. This inability to cause direct DNA damage was also shown with either therapeutic or diagnostic radiation exposure [11]. The primary thermal effect of cell phones resulted in the heating of tissue, which is of controversial clinical importance [4] [14]. Cellular device-emitted electromagnetic radiation interacts within body tissues to cause electromagnetic currents leading to changes in the microenvironment of tissues [15].

In the study performed by INTERPHONE, a possible effect of prolonged and extensive use of cell phones was described, though more investigation is needed. Recently, a meta-analysis study showed a link between acoustic neuromas and gliomas in a specific type of heavy cell phone user who tended to always use the phone on one side of the skull, identified as an ipsilateral user, compared with less frequent users and nonusers [11]. Surprisingly, the cancer risk was highest in those with prolonged cell phone use, even in those less than 20 years old.

Safety regulations for mobile phones and tablets were written in 1996 by the Federal Communication Commission in the US [16]. They made their regulations depending on levels of electromagnetic radiation that penetrated a Plexiglas head region in a simulated man weighing $200 \mathrm{lb}$. This investigation was performed to detect the specific absorption rate (SAR) (i.e. a specific rate of energy deposition in the body after exposure to electromagnetic radiation from mobile phones). The Federal Communication Commission has set an exposure limit of up to $1.6 \mathrm{watt} / \mathrm{kg}$ of tissue. Any functioning mobile phone that produces $<1.6 \mathrm{watt} / \mathrm{kg}$ is considered to be safe. The duration of exposure during an SAR test is 30 minutes and does not reflect the accumulative time of exposure to electromagnetic radiation that one may normally expect from those with prolonged and heavy use habits. 
This safe limit complies with previous regulations and studies, both theoretically and experimentally proven using simulation methodology [13]. Furthermore, FCC guidelines do not associate the risks linked with direct contact of the skin with cell phones. This is an important factor with respect to prolonged exposure to electromagnetic radiation and its direct thermal effect on the occurrence of breast cancer. The user manual of iPhone 4 advises one to carry their phone $1.5 \mathrm{~cm}$ or more away from their body [17]. Similarly, the BlackBerry Bold cell phone safety manual advises using a holster to keep the cell phone and to carry it approximately $15 \mathrm{~mm}$ away from a user's skin when using the cell phone (safety and product information 2013).

The reported four young women with breast cancer related to cell phone use are considered to comprise a case with a small sample, therefore negating a causal relationship given that millions of women use cellular devices with an insignificant occurrence rate of breast cancer. Therefore, causality cannot be inferred, and at best an indirect linkage can only be under consideration. In addition, no clear information is available to determine the women number who usually put their phones with skin contact and breasts for long periods and do not develop cancer. On the other hand, exposure time and placement site of mobile phones directly adjacent to the breast could in fact be subject to recall bias (i.e. systematic error due to differences in accuracy or completeness of recall to memory of past events or experiences) [10].

Baan et al. [14] recorded that they did not come across any study that evaluated a direct relationship between uses of cell phone and cancer of the breast. In addition, the exposure period that extended for years is considered a prolonged time factor. In general, biological effects of electromagnetic radiation on children could be up to several times greater than those on adults [18]. The dividing cells and growing tissue of the breast that occur during puberty may be particularly susceptible to harm or damage from cell phone electromagnetic radiation.

\section{Conclusion}

Cell phone use continues to increase rapidly. As of a few years ago, young women and children increasingly carry all types of mobile devices, including cell phones and tablets. They tend to be heavy users in terms of time spent in close contact with their cell phone, even while sleeping. Until more data are obtained regarding inappropriate use and carrying a cell phone, and their association with breast cancer risk, safety measures should be heeded to avoid any possible risks from cell phone use. Strenuous efforts should be made to encourage users of cell phone to follow mobile device manufacturers' recommendations and avoid skin contact. Further research in this area is recommended.

\section{References}

[1] American Cancer Society (2011) Breast Cancer Facts and Figures 2011-2012. American Cancer Society, Atlanta.

[2] Schüz, J., Jacobsen, R., Olsen, J.H., Boice Jr., J.D., McLaughlin, J.K. and Johansen, C. (2006) 
Cellular Telephone Use and Cancer Risk: Update of a Nationwide Danish Cohort. Journal of the National Cancer Institute, 98, 1707-1713. http://dx.doi.org/10.1093/jnci/djj464

[3] Volkow, N.D., Tomasi, D., Wang, G.-J., et al. (2011) Effects of Cell Phone Radiofrequency Signal Exposure on Brain Glucose Metabolism. Journal of the American Medical Association, 305, 808-813. http://dx.doi.org/10.1001/jama.2011.186

[4] Acar, G.O., Yener, H.M., Savrun, F.K., Kalkan, T., Bayrak, I. and Enver, O. (2009) Thermal Effects of Mobile Phones on Facial Nerves and Surrounding Soft Tissue. Laryngoscope, 119, 559-562. http://dx.doi.org/10.1002/lary.20070

[5] (2013) The World in 2011. ICT Facts and Figures, 6 June.

[6] Söderqvist, F., Hardell, L., Carlberg, M. and Hansson Mild, K. (2007) Ownership and Use of Wireless Telephones: A Population-Based Study of Swedish Children Aged 7 - 14 Years. BMC Public Health, 7, 105. http://dx.doi.org/10.1186/1471-2458-7-105

[7] Ng, A.K. and Travis, L.B. (2009) Radiation Therapy and Breast Cancer Risk. Journal of the National Comprehensive Cancer Network, 7, 1121-1128.

[8] Cardis, E. (2010) Brain Tumour Risk in Relation to Mobile Telephone Use: Results of the INTERPHONE International Case-Control Study. International Journal of Epidemiology, 39, 675-694. http://dx.doi.org/10.1093/ije/dyq079

[9] West, J.G., Kapoor, N.S., Liao, S.-Y., Chen, J.W., Bailey, L. and Nagourney, R.A. (2013) Multifocal Breast Cancer in Young Women with Prolonged Contact between Their Breasts and Their Cellular Phones Case Reports in Medicine. Case Reports in Medicine, 2013, Article ID: 354682.

[10] Hardell, L., Carlberg, M. and Mild, H.K. (2011) Pooled Analysis of Case-Control Studies on Malignant Brain Tumours and the Use of Mobile and Cordless Phones Including Living and Deceased Subjects. International Journal of Oncology, 38, 1465-1474. http://dx.doi.org/10.3892/ijo.2011.947

[11] Hardell, L., Carlberg, M. and Hansson, K. (2013) Use of Mobile Phones and Cordless Phones Is Associated with Increased Risk for Glioma and Acoustic Neuroma. Pathophysiology, 20, 85-110. http://dx.doi.org/10.1016/j.pathophys.2012.11.001

[12] IARC (2011) IARC Monographs on the Evaluation of Carcinogenic Risks to Humans. NonIonizing Radiation, Part II: Radiofrequency Electromagnetic. Vol. 102, IARC Press, Lyon.

[13] Abdalla, S. and Jastaniah, S.D. (2008) Effect of Energy Carried by Radio-Frequency Radiation on the Weakest Bond in a DNA Molecule Proceedings i-TCE.

[14] Baan, R., Grosse, Y., Lauby-Secretan, B., et al. (2011) Carcinogenicity of Radiofrequency Electromagnetic Fields. The Lancet Oncology, 12, 624-626.

http://dx.doi.org/10.1016/S1470-2045(11)70147-4

[15] Brenner, D., Doll, J., Goodhead, D.T., et al. (2003) Cancer Risks Attributable to Low Doses of Ionizing Radiation: Assessing What We Really Know. Proceedings of the National Academy of Sciences of the United States of America, 100, 13761-13766.

[16] Röösli, M., Rapp, R. and Braun-Fahrländer, C. (2003) Radio and Microwave Frequency Radiation and Health: An Analysis of the Literature. Gesundheitswesen, 65, 378-392.

[17] (2013) I Phone 4 Important Product Information Guide. Safety and Product Information. Blackberry Bold 9900/9930 Smartphones, 7 June.

[18] Gandhi, O.P., Morgan, L.L., De Salles, A.A., Han, Y.-Y., Herberman, R.B. and Davis, D.L. (2012) Exposure Limits: The Underestimation of Absorbed Cell Phone Radiation, Especially in Children. Electromagnetic Biology and Medicine, 31, 34-51. http://dx.doi.org/10.3109/15368378.2011.622827 
Submit or recommend next manuscript to SCIRP and we will provide best service for you:

Accepting pre-submission inquiries through Email, Facebook, LinkedIn, Twitter, etc. A wide selection of journals (inclusive of 9 subjects, more than 200 journals)

Providing 24-hour high-quality service

User-friendly online submission system

Fair and swift peer-review system

Efficient typesetting and proofreading procedure

Display of the result of downloads and visits, as well as the number of cited articles

Maximum dissemination of your research work

Submit your manuscript at: http://papersubmission.scirp.org/ 